\title{
Питання психології
}

УДК 159.923.2

DOI: $10.33099 / 2617-6858-21-62-4-62-68$

Козак О. Ю. Уманський держсавний

педагогічний університет імені Павла Тичини

https://orcid.org/0000-0002-8164-0733

\section{ЩОДО ОБГРУНТУВАННЯ ТЕОРЕТИЧНОЇ МОДЕЛІ ПРОФЕСІЙНОЇ АДАПТАЦІЇ МАЙБУТНІХ ПЕДАГОГІВ}

У статті здійснено обтрунтування теоретичної моделі професійної адаптаиії майбутніх педагогів. Зазначається, щьо теоретична модель професійної адаптації майбутніх педагогів містить структурно-функиіональний і динамічний компоненти.

Ключові слова: модель; професійна адаптаиія; майбутній педагог; структурно-функціональний компонент; динамічний компонент.

Вступ. На цей час усе більш очевидною стає тенденція оцінки якості професійної підготовленості педагога, традиційно пов'язаної із засвоєнням професійних компетенцій, які характеризують готовність до праці у професії. Однак професійна діяльність педагогів вимагає від них не лише сформованості професійних компетенцій, а й розвитку професійно важливих особистісних якостей, які не в меншій мірі впливають на ефективне входження у професію. Значущими показниками професійного розвитку педагогів $є$ засвоєння норм і вимог професійної діяльності, професійна адаптація, усвідомлення своєї приналежності до професійної групи, а також закріплення професійних інтересів, що обумовлюють ефективність їхньої професійної діяльності. Ці показники складають змістовну основу професійної адаптації, яка $€$ одним 3 центральних механізмів інтегрування особистості у професію i яка нівелює неузгодженість у системі «людина професія».

Контент-аналіз відгуків про випускників Уманського державного педагогічного університету імені Павла Тичини засвідчив, що практично в всіх 3 них, поряд 3 оцінками високої професійної підготовленості, відзначаються певні недоліки, які пов'язані із недостатнім рівнем розвиненості професійних особистісних якостей, що ускладнюють швидке включення у професійну діяльність та успішне іiі

виконання. На негативний стан справ вказує неузгодженість домагань педагогів та очікувань МОН України щодо якості та тривалості їхньої роботи. Це може свідчити про неадекватність вибору ними спеціальності та професії з т. з. відповідності професійної готовності до виконання вимог професійної діяльності.

Зазначений стан справ свідчить про те, що існуюча система професійного відбору та підготовки педагогічних кадрів не призводить до вирішення проблеми їхньої успішної професійної адаптації $\mathrm{i}$ не відповідає належною мірою сучасним вимогам. Створення умов для реалізації професійних інтересів, потреб, вибору професійної діяльності завжди було основним завданням системи освіти. Недооцінка ролі психологічних чинників у професійній підготовці педагогічних кадрів робить роботу суб'єктів освітнього процесу малоефективною.

Подолання цієї невідповідності передбачає вирішення цілої низки наукових завдань, пов'язаних із реалізацією нових освітніх підходів, одним 3 яких є виявлення особливостей професійної адаптації здобувачів вищої освіти під час їхнього навчання у виші.

Теоретичне підгрунтя. Важлива роль в усвідомленні необхідності створення адекватних умов для повноцінної підготовки педагога як суб'єкта професійної діяльності належить психології. В аспекті наукового 


\section{Питання психології}

вивчення проблема професійної адаптації людини знайшла своє відображення у безлічі досліджень зарубіжних та українських авторів.

У своїх роботах представники західної психологічної науки заклали теоретичні основи дослідження професійної адаптації і розглядали ії як: процес входження людини в специфічну інституційне середовище (П.Д.Бергер; Т.Лукман), окремий етап адаптації особистості (Е.Еріксон), процес засвоєння конвенціональних норм організації (Дж. Мід; Т.Шибутани), продукт рольової взаємодії (Дж. Мід; І.Гоффман).

Великий внесок у дослідження професійної адаптації 3 позицій професійного розвитку особистості внесли К.О. Альбуханова-Славська, А.В.Брушлинский, С.О. Клімов, О.М. Кокун, В.C. Корольчук, А.К. Маркова, О.Р. Охременко, М.С. Пряжников, B.І.Слободчиков та ін. В їхніх роботах розглядалися проблеми психологічних ефектів адаптації, закономірності професіоналізації особистості, зумовлені віковими етапами життєдіяльності, сутність, структура та механізми професійної адаптації.

Методи дослідження. Теоретичний аналіз, синтез, узагальнення, порівняння.

Результати і обговорення. Теоретичний аналіз наукових підходів до проблеми професійної адаптації дозволяє обгрунтувати модель, що в основі розуміння психологічного змісту i структури професійної адаптації педагогів. Ця модель містить систематизовані уявлення щодо сутності, процесуально динамічних особливостей, чинників та умов, а також критеріїв оцінки, що дозволяють найбільш повно охарактеризувати досліджуваний феномен - психологічні особливості професійної адаптації.

Провідну роль у розумінні процесу інтеграції фахівця у професію відіграє наявність суперечності у системі «людина професія». Ця суперечність загострює наявність відмінностей між нормативними вимогами професії до людини та очікуваннями самого суб'єкта від професії, а так само можливостями задовольняти потреби у межах професійної діяльності. Роль професійної адаптації полягає у безперервній діагностиці, розумінні наявності та характеру цієї суперечності на кожному 3 етапів професійного розвитку, обранні шляхів ऑii вирішення. У межах розроблюваної теоретичної моделі професійної адаптації майбутніх педагогів головним завданням $є$ опис психологічних особливостей, властивостей особистості, включеної у професійну діяльність. Однак, без врахування умов, в яких належить виконувати професійні обов'язки (соціального середовища), ця модель може мати однобокий, незавершений характер. Норми, правила поведінки, регламентація діяльності також певним чином справляють вплив на професійну адаптацію. Значна частина професійних норм для майбутніх педагогів $\epsilon$ новими i мають професійно виражений характер і можуть відрізнятись і доповнювати загальносоціальні.

Методологічною основою виокремлення процесу вторинної адаптації та його елементів стали наукові доробки представників школи символічного інтеракціонізму (Дж. Мід, Т.Шибутани). На їхню думку, вторинна адаптація відбувається тоді, коли колишні стандарти поведінки стають недостатніми або неадекватними. Нові патерни поведінки формуються, коли людина вступає до нової організації (професійної групи) і розвиває інші типи активності (професійні дії), які найбільш відповідають новим обставинам. Дезадаптована особистість часто відчуває труднощі, або взагалі не здатна здійснювати професійні функції, брати участь у злагоджених діях, не засвоює і порушує виробничі норми, що визначають функціональність організації.

Також методологічною основою розробки теоретичної моделі виробничої адаптації стали ідеї Г.М. Андрєєвої, на думку якої порушення процесу професійної адаптації не дає можливості якісно здійснювати функції входження особистості 


\section{Питання психології}

у професійне середовище і відтворення системи соціальних відносин, що веде до труднощів у професійній діяльності, порушень виробничої дисципліни.

Свій особливий прояв професійна адаптація знаходить у конкретній ситуації суперечності між готовністю майбутнього педагога інтегруватися у професію i вимогами професійної діяльності. Усвідомлення цієї суперечності передбачає прояв активності майбутнього фахівця, його особистого професійних i психологічних ресурсів в процесі становлення особистості як фахівця (вирішенні суперечності).

Професійна адаптація обумовлюється специфікою певного етапу професіоналізації i виникає як наслідок цієї суперечності у системі «людина - професія» і необхідності іi подолання. Породжувані сукупністю зовнішніх і внутрішніх умов проблемні ситуації багато у чому визначають детермінучий i змістовний аспекти професійної адаптації.

Аналіз наукових праць свідчить про пріоритетність внутрішньої системи критеріїв оцінки професійної адаптації, отже, успішність вирішення виникаючих суперечностей значною мірою залежить від наявного рівня розвитку професійнопсихологічного ресурсу особистості [1]. 3 врахуванням виокремлених методологічних підходів до досліджуваної проблеми розроблено теоретичну модель професійної адаптації майбутніх педагогів, що містить структурно-функціональний $\mathrm{i}$ динамічний блоки. Структурно-функціональний блок представлений компонентами професійної адаптації (професійною інтеріоризацією, професійною адаптацією, професійною ідентичністю, професійним цілепокладанням) і нормативними вимогами професії. Динамічний блок є основою моделі професійної адаптації. Він представлений суперечністю між зовнішніми (нормативними) вимогами та умовами, в яких майбутній педагог перебуває i його професійними цінностями, професійною адаптацією, професійною ідентичністю, професійними цілями. Рушійною силою процесу професійної адаптації є: усвідомлення майбутніми педагогами цієї суперечності шляхом зіставлення своїх професійно значущих якостей із нормативними вимогами педагогічної професії; розуміння необхідності докладання власних зусиль для ефективного входження у цю професію. Тобто, наявну суперечність можна розглядати як внутрішній стимул для трансформації професійно значущих змін в особистості здобувачів вищої освіти.

Усвідомлення проблемної ситуації запускає процес співвіднесення сформованих професійно важливих якостей фахівця із формальними вимогами професії i $\epsilon$ потужним джерелом підвищення професійної активності особистості. У реальній ситуації вирішення суперечності залежить від розвитку компонентів професійної адаптації (професійної інтеріоризації, професійної адаптації, професійної ідентичності, професійного визначення мети), рівень розвитку яких обумовлює конкретну стратегію професійної адаптації, яка сприяє або перешкоджає ефективній інтеграції в обрану спеціальність.

Кожному із виокремлених компонентів професійної адаптації відповідають певні психологічні якості майбутнього педагога, сформовані в процесі навчання, які i дозволяють йому успішно або неуспішно інтегруватися у професійне середовище. Розвиток цих компонентів у своїй сукупності $\epsilon$ значущим елементом системи психологічного забезпечення ефективного входження у педагогічну професію, які підвищують якість професійно-педагогічної діяльності.

Першим психологічним компонентом, який визначає успішність професійної адаптації, $\epsilon$ професійна інтеріоризація. Змістовною характеристикою цього компонента $\epsilon$ процес включення норм, правил поведінки і цінностей професії до власної структури цінностей [2]. Інтеріоризаційний компонент розглядається як динамічний процес засвоєння професійних ролей, трансформування норм i цінностей педагогічної праці у внутрішню 


\section{Питання психології}

нормативно-ціннісну структуру педагога, результатом якого $\epsilon$ формування системи локусу контролю, що регулює його професійну активність.

Професійна інтеріоризація в процесі професійної адаптації особистості є першою, так як майбутній педагог ще до початку вступу до вишу має певні уявлення про цінності і традиції педагогічної професії [3]. Певні міркування щодо норм і цінностей педагогічної у юнаків і дівчат формуються за допомогою організації професійного орієнтування у школі, повсякденного спілкування із вчителями, перегляду кінофільмів, читання книг, засобів масової інформації та ін. Однак ці уявлення, завдяки сформованому образу професії педагога можуть не відповідати або бути не повними щодо реально існуючих норм і цінностей педагогічної діяльності. Як наслідок цього, молода людина, вступаючи до педагогічного вишу, відноситься диференційовано до іiі цінностей і норм, тобто окремі приймає, а інші відхиляє.

Поступивши до педагогічного вишу, здобувач вищої освіти (через певну регламентацію життєдіяльності) починає адаптуватися до реально існуючих умов професійної діяльності. Тому другим психологічним компонентом, що формує пристосувальні якості майбутнього педагога до завдань та умов професійної діяльності, $€$ професійна адаптація.

\section{Сутнісною}

характеристикою професійної адаптації $€$ пристосування людини до системи соціальних, соціальнопсихологічних i професійних відносин в процесі професійної діяльності. Цей компонент визначає якість взаємодії людини у професійному середовищі. Оскільки процес пристосування має взаємозалежний характер, то його результатом може бути гармонізація спільної діяльності суб'єктів педагогічної діяльності. Порушення такої взаємодії може привести до невиконання професійних завдань.

Професійна адаптація здійснюється завжди, коли з'являється та актуалізується потреба у злагодженій спільній діяльності.
Джерелом такої потреби $\epsilon$ об'єктивні суперечності, що виникають у системі «особистість - професія». Оскільки значна частина завдань педагогічної діяльності вимагає спільних зусиль (професія), то готовність i вміння діяти у команді (особистість) вимагає від майбутнього фахівця активізувати власні пристосувальні можливості. Адаптаційна ситуація виникає у разі неузгодженості системи та іiі вирішення відбувається в процесі професійної адаптації - пристосування не лише суб'єктів професійної діяльності один до одного, але до змістовних характеристик професійної активності через засвоєння професійних ролей.

Третім психологічним компонентом, що детермінує професійну адаптацію, $є$ професійна ідентифікація. Сутність цього компонента полягає у фіксації (визначенні) майбутнім педагогом усвідомленого i прийнятого сенсу його позиції $\mathrm{y}$ професійному просторі. Процес співвіднесення себе в професійному просторі відбувається в формально структурованому професійному просторі. За допомогою професійної ідентифікації відбувається розвиток поглядів майбутнього педагога на себе, своє становище у професійному співтоваристві, інших його членів і згодом співвіднесенням із конкретною професійною групою або референтним однокурсником. Така фіксація приналежності до професійної групи дозволяе майбутньому педагогу задовольнити потребу у захищеності, забезпечує комфортне положення у професійному середовищі, колективі, співвіднесення із референтним однокурсником - це й складає вектор його професійного розвитку.

Пусковим механізмом формування професійної ідентичності майбутнього педагога $\epsilon$ наявність потреби у приналежності до професійного колектива, задоволення якої забезпечує не лише його захищеність, але і можливість реалізації себе як професіонала. Цей пусковий механізм, забезпечуючи включеність особистості у професійну групу, дозволяє організації 


\section{Питання психології}

задовольнити соціальні потреби - навчання і виховання підростаючого покоління.

Психологічна ідентичність може бути описана 3 двох позицій: перша - розгляд процесу з позицій групової приналежності, визнання та утвердження статусу усередині групи (зовнішній критерій), друга передбачає вивчення розуміння суб'єктом професійних відносин, свого місця у професійному просторі (внутрішній критерій). Функціональність професійної ідентичності майбутнього педагога значною мірою визначається внутрішнім критерієм, оскільки пріоритетне ототожнення себе із формальною або неформальною групою визначає ефективність входження у професію. Однак слід зазначити, що, 3 одного боку, зовнішня згода із професійними цінностями не завжди може бути викликана внутрішнім прийняттям через різні джерела їхньої трансляції. Наприклад, можна припустити, що здобувач вищої освіти може співвідносити себе із неформальною групою, а не професійним колективом. 3 іншого боку, він може негативно ставитися до запропонованої йому позиції, але зовні погоджуватися з нею. Така ситуація виникає у разі значного соціального статусу позиції, iii престижності. Така суперечливість породжує внутрішній конфлікт смислів, ролей, цінностей та ін.

Четвертим компонентом, розвиненість, якого сприяє ефективності професійної адаптації, $\epsilon$ професійне цілепокладання. Цілеорієнтована поведінка визначається такими характеристиками: наявність мети дії або розвитку (пріоритетні цілі, найближчі / довгострокові цілі та ін.); розуміння власних цілей; домінування цілей над засобами їхнього досягнення (в основі вибору засобу досягнення цілей оцінка співвіднесення трудовитрат i результату); розрахунок можливого ефекту результатів досягнення цілей [4]. Виходячи із цього, можна відзначити, що для якісної професійної діяльності необхідною умовою $\epsilon$ iі професійна орієнтованість. Елементи i характер розвитку целеорієнтірованої поведінки визначають функції професійного цілепокладання: проективна, що припускає наявність спільного проекту, цілі-проекту, кар'єрного плану життя; ціннісна, орієнтована на об'єкти професійного простору (надає їм цінність, особистісну значущмість); нормативна, що припускає орієнтацію у професійній поведінці на професійно схвалювані та очікувані норми; самоспрямованості, орієнтованої на себе як на професіонала.

Характеристика загальних, особливих i специфічних рис і тенденцій функціонування психологічних компонентів, регулюючих професійну діяльність майбутніх педагогів дозволяє розглядати процес їхньої професійної адаптації через призму взаємодії чотирьох вищезазначених компонентів: професійної інтеріоризації, професійної адаптації, професійної ідентичності та професійного цілепокладання. Структурні компоненти професійної адаптації, виконуючи кожен свою функцію, не лише взаємопов'язані, а й взаємообумовлені: починаючись 3 процесу включення професійних цінностей педагогічної праці у внутрішню структуру цінностей особистості (професійна інтеріоризація), переходить у пристосування до виконання завдань у складі групи, а також умов педагогічної праці (професійна адаптація). Формування професійних патернів поведінки як би «запускає» професійну ідентичність, визначає вектор професійного розвитку (професійне цілепокладання). Однак це не означає, що професійне цілепокладання $\epsilon$ заключним етапом у ланцюжку формування професійної адаптації. 3 цього випливає лише те, що досягнуті професійні цілі втрачають свою актуальність, нові іiі набувають, а процес включення цінностей професії до внутрішньої структури особистості активізується завжди, коли виникають нові цінності, про які майбутній педагог раніше не знав (різного роду позитивні ініціації), а вирішення інтеріоризаційних проблем активізує процес пристосування i т. п. Взаємозалежне функціонування компонентів професійної адаптації являє собою своєрідні зусилля 


\section{Питання психології}

майбутнього педагога для ефективної його інтеграції у професію.

Висновки. Таким чином, дослідження різних шкіл і концептуальних підходів до аналізу процесу професійної адаптації дозволяють зробити висновки, що досліджуваний процес має дискретний характер, тобто настає і закінчується у певних життєвих циклах розвитку людини. Результати багатьох психологічних досліджень дозволяють відзначити імперативність внутрішньої системи регуляторів професійної адаптації, до якої вони звертаються для вирішення професійних завдань.

Теоретичний аналіз проблеми дозволив уточнити поняття професійна адаптація майбутніх педагогів - це дискретний процес, що містить засвоєння норм i цінностей педагогічної праці, пристосування до умов професійної діяльності, ототожнення себе із професією i професійною спільнотою, визначення та узгодження цілей професійного розвитку, що забезпечує ефективну інтеграцію у професію.

Психологічний зміст професійної адаптації містить: структурування симпатій до обраної спеціальності; пристосування до вимог професії і засвоєння професійних норм поведінки; ототожнення себе із певною професією i професійною спільнотою; визначення та узгодження професійних цілей, їхня реалізації в обраній професії. У структурному відношенні професійна адаптація майбутніх педагогів містить соціалізаційні компоненти (професійну інтеріоризацію, професійну адаптацію, професійну ідентифікацію, професійне цілепокладання).

Теоретична модель професійної адаптації майбутніх педагогів містить структурно-функціональний $\mathrm{i}$ динамічний компоненти. У структурно-функціональному відношенні теоретична модель детермінації професійної адаптації майбутніх педагогів складається із суб'єктів професійної взаємодії: особистість, яка виконує свої основні функції як суб'єкт професійної діяльності та нормативні вимоги професійної діяльності. у динамічному відношенні виокремлюються суперечності між зовнішніми (нормативними) вимогами, умовами, в яких майбутній педагог перебуває, i його актуальними планами, цілями, можливостями, це й $\epsilon$ основою моделі детермінації його професійної адаптації.

\section{Список використаних джерел}

1. Галян А.І. Особистісні ресурси адаптації майбугніх медичних працівників до професійної діяльності: дис. ... канд. психол. наук. Луцьк: Східноєвропейський нац. ун-т ім. Лесі Українки, 2016. 234 с.

2. Мицько В.М. Психологічні особливості аксіогенезу майбутніх психологів: дис... канд. психол. наук. Прикарпатський національний університет імені Василя Стефаника. Івано-Франківськ, 2007. 195 с.

3. Міхно К.О. Динаміка уявлень студентів-психологів про майбутню професію: дис... канд. психол. наук. Київський національний ун-т ім. Тараса Шевченка. К., 2008. 210 с.

4. Наумова Н.Ф. Социологические и психологические аспекты целенаправленного поведения. М., 1988. C. $43-46$.

\section{References}

1. Galjan A.I. (2016) Osobystisni resursy adaptacii' majbutnih medychnyh pracivnykiv do profesijnoi' dijal'nosti [Personal resources of adaptation of future medical workers to professional activity]: dys. ... kand. psyhol. nauk. Luc'k: Shidnojevropejs'kyj nac. un-t im. Lesi Ukrai'nky. 234 s. (in Ukranian)

2. Myc'ko V.M. (2007) Psyhologichni osoblyvosti aksiogenezu majbutnih psyhologiv [Psychological features of axiogenesis of future psychologists]: dys... kand. psyhol. nauk. Prykarpats'kyj nacional'nyj universytet imeni Vasylja Stefanyka. Ivano-Frankivs'k. 195 s. (in Ukranian)

3. Mihno K.O. (2008) Dynamika ujavlen' studentiv-psyhologiv pro majbutnju profesiju [Dynamics of students-psychologists' ideas about the future profession]: dys... kand. psyhol. nauk. Kyi'vs'kyj nacional'nyj un-t im. Tarasa Shevchenka. K.. 210 s. (in Ukranian).

4. Naumova N.F. (1988) Sociologicheskie i psihologicheskie aspekty celenapravlennogo povedenija [Sociological and psychological aspects of purposeful behavior]. M.. S. 43-46. (in Russian). 


\section{Питання психології}

\section{Резюме \\ Козак О. Ю. Уманський державний \\ педагогічний університет імені Павла Тычины \\ ОБОСНОВАНИЕ ТЕОРЕТИЧЕСКОЙ МОДЕЛИ \\ ПРОФЕССИОНАЛЬНОЙ АДАПТАЦИИ БУДУЩИХ ПЕДАГОГОВ}

В статье осуществлено обоснование теоеретической модели профессиональной адаптации будущих педагогов. Отмечается, что теоретическая модель профессиональной адаптащии будущих педагогов содержит структурно-функииональный и динамический компоненты.

Ключевые слова: модель; профессиональная адаптащия; будущий педагог; структурнофункциональный компонент; динамический компонент.

\section{Summary}

Kozak $\boldsymbol{O}$. U. Uman state pedagogical university named after Pavlo Tychyna

\section{SUBST ANTIATION OF THE THEORETICAL MODEL OF PROFESSIONAL ADAPTATION OF FUTURE TEACHERS}

The article substantiates the theoretical model of professional adaptation of future teachers. Theoretical analysis of scientific approaches to the problem of professional adaptation allows to substantiate the model that underlies the understanding of the psychological content and structure of professional adaptation of teachers. This model contains systematized ideas about the nature, procedural and dynamic features, factors and conditions, as well as evaluation criteria that allow the most complete description of the phenomenon under study - the psychological features of professional adaptation.

Theoretical analysis of the problem allowed to clarify the concept of professional adaptation of future teachers - a discrete process that includes learning the norms and values of teaching, adaptation to the conditions of professional activity, identification with the profession and the professional community, definition and coordination of professional development goals.

The psychological content of professional adaptation includes: structuring sympathies for the chosen specialty; adaptation to the requirements of the profession and mastering professional norms of behavior; identification with a certain profession and professional community; definition and coordination of professional goals, their implementation in the chosen profession. Structurally, the professional adaptation of future teachers contains socialization components (professional internalization, professional adaptation, professional identification, professional goal setting).

The theoretical model of professional adaptation of future teachers contains structural-functional and dynamic components. In structural and functional terms, the theoretical model of determining the professional adaptation of future teachers consists of subjects of professional interaction: a person who performs its main functions as a subject of professional activity and regulatory requirements of professional activity. In dynamic terms, the contradictions between external (regulatory) requirements, the conditions in which the future teacher is, and his current plans, goals, opportunities, this is the basis of the model of determining his professional adaptation.

Key words: model; professional adaptation; future teacher; structural and functional component; dynamic component.

Recelved/Поступила: 23.09.21. 